\title{
A NEW FOSSIL CONIFER FROM THE TRIASSIC OF NORTH AMERICA: IMPLICATIONS FOR MODELS OF OVULATE CONE SCALE EVOLUTION
}

\author{
Brian J. Axsmith,' ${ }^{1}$ Thomas N. Taylor, and Edith L. Taylor \\ Department of Botany and Natural History Muscum and Biodiversity Research Center. \\ University of Kansas, Lawrence, Kansas 66045, U.S.A.
}

\begin{abstract}
Vegetative shoots, ovulate cones, and putative seeds of Conewagia longiloba gen. et sp. nov., a fossil conifer from the Upper Triassic New Oxford Formation of York County, Pennsylvania, are described. Vegetative shoots represent up to three orders of branches bearing robust, spirally arranged leaves. Leaves are somewhat flattened and falcate with a papillate cuticle. Ovulate cones bear closely spaced, helically arranged bract-scale complexes. Ovulate cone scales possess a stalklike basal portion fused to a subtending bract, with an expanded upper part consisting of 11 proximally fused foliar components oriented in a single plane. Each component forms a narrow, toothlike lobe on the distal cone scale margin. The acute apex of the bract is free and lies adjacent to a groove in the abaxial cone scale surface. Dispersed sceds with a longitudinal ridge or rudimentary wing may have been produced by this conifer. The 11 ovulate cone scale foliar components of $C$. longiloba are the greatest number known in any early Mesozoic conifer, and the taxon helps to fill a previously unappreciated temporal gap in the fossil record between the Paleozoic and modern conifers that have numerous ovulate cone scale components.
\end{abstract}

\section{Introduction}

Conifers comprise the taxonomically and ecologically dominant group of nonflowering seed plants in the modern flora, and were a major component of many paleofloras beginning in the Late Carboniferous and Early Permian (Miller 1977). Recently, there have been important advances in our understanding of the earliest conifers (Kerp and Clement-Westerhof 1991; Mapes and Rothwell 1991; Schweitzer 1996) as well as increased interest in the developmental biology (Takaso and Tomlinson 1989, 1990) and systematics of modern forms, based on morphological and molecular data sets (Hart 1987; Chaw et al. 1995). Despite this resurgence of interest in conifer phylogeny, our understanding of many early Mesozoic forms is poor (Axsmith and Taylor 1997). This lack of understanding is unfortunate, since several modern conifer families, including the Podocarpaceae (Townrow 1967a), Pinaceae (Delevoryas and Hope 1987), Taxodiaceae (Yao et al. 1997), and Araucariaceae (Stockey 1982), first appear at that time.

Interpretations of several early Mesozoic conifers that have historically played prominent roles in phylogenetic hypotheses, such as Voltzia and Glyptolepis, have been based on poorly preserved material from the Triassic of Europe (Florin 1951; Mägdefrau 1963; Axsmith and Taylor 1997). New insights into this crucial interval in conifer evolution appeared in a series of articles by Delevoryas and Hope (1973, 1975, 1981, 1987), which demonstrated that the Late Triassic Pekin Formation of North Carolina contains a diverse record of conifers including Compsostrobus neotericus, Florinostrobus andrewsii, and Metridiostrobus palissyaeoides. Conifers also occur at other Triassic and Jurassic localities in eastern North America, but they have not yet been adequately described. For example, conifers

'Author for correspondence and reprints.

Manuscript received September 1997; revised manuscript received October 1997. were first noted from the Late Triassic New Oxford Formation of Pennsylvania by Wanner and Fontaine (1900). Cornet (1977) collected additional material from nearby localities and noted that several of the conifers were originally misidentified, including an ovulate cone that had been mistaken for leafy shoots of the ginkgophyte Baiera muensteriana. Cornet (1977) assigned this cone to the European genus Glyptolepis and noted that it was attached to vegetative shoots erroneously assigned to Palissya sphenolepis by Wanner and Fontaine (1900). On the basis of a reexamination of previously collected specimens, as well as recently collected material that provides additional morphological information, we suggest that this conifer represents a distinct genus. We further suggest that the ovulate cone scale structure of this form may help fill an important but previously unappreciated temporal gap in the conifer fossil record.

\section{Material and Methods}

The specimens used in this study come from shales of the middle New Oxford Formation, which has been dated as Late Triassic (late Carnian) based primarily on palynomorphs (Cornet 1977). The plant-bearing exposures occur on private property in ravines and small tributary streambeds along the southeast bank of Little Conewago Creek, ca. 2.1 $\mathrm{km}$ southwest of its junction with Conewago Creek near Manchester Township, York County, Pennsylvania (York Haven 7.5-min quadrangle). Leafy shoots of the new conifer are relatively rare, and only two ovulate cones and an isolated cone scale have been found. Dispersed seeds possibly belonging to this conifer are found singly and in clusters. Other fossil conifers from the Little Conewago Creek localities include abundant shoots of Pagiophyllum diffusum with attached ovulate cones of an undescribed majonicaceous conifer (Axsmith and Taylor 1997) and leafy shoots of $P$. simpsonii (Cornet 1977). Next in abundance after the conifers are winged cupules and shoots of the enigmatic seed plant Dinophyton and unidentified fernlike leaves with reticulate venation. The Little Conewago Creek locality produces a less diverse flora than does that of the New Oxford For- 
mation exposures at York Haven, which were also described by Wanner and Fontaine (1900).

The plant fossils are preserved as casts, impressions, and compressions with variable preservation of the cuticle. The cuticles are too brittle and coalified to be cleared with standard chemical agents such as Schulz's reagent. Fluorescence microscopy is also ineffective at resolving the cuticular features of this material. Some cuticle fragments were removed with fine needles and brushes, mounted on stubs, and sputter coated for SEM. The shale surfaces were briefly etched with 49\% hydrofluoric acid and rinsed with distilled water to remove dark mineral stains and to increase specimen contrast. Ovulate cone scales and bracts were exposed with fine needles. Impressions lacking contrast with the surrounding matrix were photographed under incident light.

\section{Conifer Ovulate Cone Scale Morphology and Terminology}

It is generally agreed that the ovulate cone scale complex of conifers is a highly modified, fertile dwarf-shoot subtended by a bract (Florin 1951). In many of the earliest conifers, such as Emporia, the fertile dwarf-shoots possess a distinct axis with as many as 30 attached foliar components (Mapes and Rothwell 1991). Some of these foliar components are megasporophylls, and others are probable homologs of vegetative leaves. In the Early Permian conifer Kungurodendron, some of the fertile dwarf-shoot foliar components represent sterilized megasporophylls (Meyen 1997). Subsequent modifications of the fertile dwarf-shoot in different lineages have obscured this primitive morphological arrangement to various degrees. In groups such as the Pinaceae, the fertile dwarf-shoot is completely flattened with the foliar components fused so that no external indications of them remain. In some other fossil and modern conifers, for example, $\mathrm{Co}$ newagia longiloba, the fertile dwarf-shoot bears foliar components that are partially fused basally but form free lobes or teeth on the distal margin. On the basis of comparison with the earliest conifers, these lobes are interpreted as the apices of foliar components on the modified fertile dwarfshoot (Miller 1988). Since some components of the fertile dwarf-shoot may no longer be distinct as a result of complete evolutionary fusion or loss, the number of apical lobes or teeth on the cone scale represents a minimum estimate of the number of foliar components comprising the original fertile dwarf-shoot.

We present this review of conifer fertile dwarf-shoot morphology in order to address the inconsistent use of the term "scale" in the literature and to define the term as used in this article. Individual foliar components of the fertile dwarfshoot are sometimes referred to as scales, especially those of early conifers with relatively unmodified fertile dwarfshoots. This terminology may be adequate when dealing with Paleozoic conifers, but it is potentially confusing when applied broadly, since in more derived forms, including most Mesozoic and modern taxa, the entire modified dwarf-shoot has historically been referred to as the scale. As a result, the "scales" of Paleozoic and more derived conifers are not strictly homologous structures.

In this article, we refer to the discernible appendages of the fertile dwarf-shoot as foliar components, for the reasons discussed above. The terms "cone scale" or "ovulate cone scale" refer to the entire modified dwarf-shoot. "Bract-scale complex" refers to an individual ovulate cone scale and its subtending bract. We find this terminology to be most useful for adequately describing and comparing this new fossil co- nifer on the basis of our current understanding of the homologies among fossil and recent conifer ovulate cones. Modifications of this terminology may be required as more is learned about fossil and recent conifer ovulate cones.

\section{Resulis}

Systematics

Division-Coniferophyta

Class-Coniferopsida

Order-Coniferales

Genus-Conewagia gen. nov. (diagnosis same as for type species)

\section{Type Species}

Conewagia longiloba sp. nov. (figs. 1-10). Vegetative branches of at least three orders bearing spirally arranged leaves; leaves with a single midvein, falcate to slightly spreading, dorsiventrally flattened, slightly constricted at the base, gradually tapering to an acute apex, leaf cuticle with rows of prominent papillae on both surfaces; ovulate cones solitary and terminal on leafy branches, cone axis robust with closely spaced, helically arranged bract-scale complexes; ovulate cone scales with stalklike base and expanded apical portion composed of 11 equal foliar components oriented in a single plane, components fused proximally and continuing distally as elongate, narrow, toothlike lobes; bracts robust, fused to cone scale stalk, expanding slightly just below acute apex, bract apex free from expanded portion of cone scale and situated adjacent to a groove in abaxial scale surface.

\section{Holotype}

No. T1-928 (fig. 6)

\section{Paratypes}

No. T1-926 (figs. 8, 10); no. T1-927 (fig. 9); no. T1-929 (fig. 7); no. T1-933; no. T1-933 (fig. 3); no. T1-934 (figs. 1, 4); no. T1-935 (fig. 5)

\section{Disposition of Specimens}

All described specimens are deposited in the Paleobotany Division of the Natural History Museum and Biodiversity Research Center, University of Kansas, Lawrence, Kansas.

\section{Stratigraphy}

New Oxford Formation

Age

Late Triassic (late Carnian) 

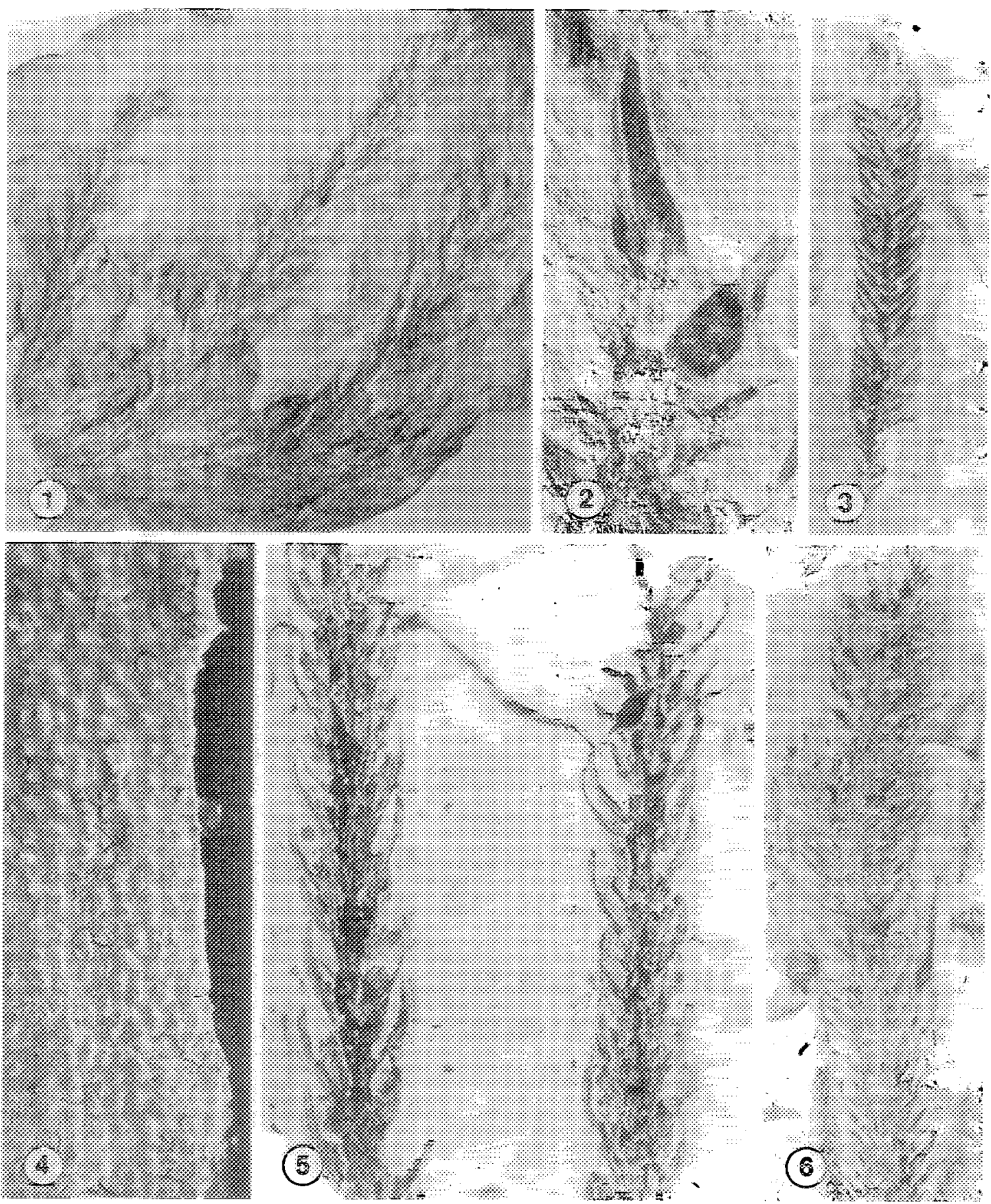

Figs. 1-6 Conewagia longiloba, shoots, leaf cuticle, and attached cone. Fig. 1, Attached penultimate and ultimate leafy shoots with attached leaves. Impression photographed under extreme incident light. No. T1-934. $\times 1.0$. Fig. 2, Two leaves in paradermal view attached to stem. Rows of papillae are visible at this magnification. No. T1-942. $\times 5.5$. Fig. 3, Branch with somewhat linear, spreading leaves. No. T1-933. $\times 0.65$. Fig. 4, SEM of cuticle fragment from leaf margin, showing rows of papillae. No. T1-934. $\times 200$. Fig. 5, Two ultimate branches with attached falcate leaves. No. T1-935. $\times 1.6$. Fig. 6, Intact cone attached to a leafy shoot. No. T1-928. $\times 0.70$.

\section{Etymology}

The generic name Conewagia refers to Little Conewago Creek in York County, Pennsylvania, along the banks of which the plant fossil localities occur. The specific epithet longiloba refers to the distal toothlike lobes of the ovulate cone scales.

\section{Description}

\section{Vegetative Morphology}

Vegetative shoots are represented mostly by isolated ultimate branches with attached leaves. A single example of two branch orders in attachment (fig. 1) has 
been found during recent collecting, and Wanner and Fontaine (1900; fig. 1, plate 32) figured a specimen with three orders of branches. Branch axes can be as much as $8.0 \mathrm{~mm}$ in diameter. All branch orders bear spirally arranged leaves similar to the Elatocladus morphotype but lack a distinct petiole (Harris 1969). Leaf laminae are dorsiventrally flattened, $1.1 \mathrm{~cm}-2.0$ $\mathrm{cm}$ long and up to $2.5 \mathrm{~mm}$ wide just above the slightly constricted base, tapering gradually to a sharp, apical tip (fig. 2). A single midvein is present. Most leaves are strongly falcate (fig. 5) but are sometimes more linear and spreading (fig. 3). Leaf cuticles possess rows of papillae averaging $10.0 \mu \mathrm{m}$ tall $\times 7.5 \mu \mathrm{m}$ wide (figs. 2, 4).

\section{Ovulate Cones}

Part and counterpart of two ovulate cones have been recovered, one of which (figs. 6-7) terminates a shoot bearing long, falcate leaves. This cone is $6.5 \mathrm{~cm}$ long $\times 3.0 \mathrm{~cm}$ wide and appears to be complete. The other cone is isolated and fragmentary but more clearly reveals the cone morphology (figs. 8-10). The cone axis is ca. $6.5 \mathrm{~mm}$ wide and bears robust bract-scale complexes arranged in a tight helix. The ovulate cone scale consists of a basal stalklike portion $2.8 \mathrm{~mm}$ thick $X$ $9.0 \mathrm{~mm}$ long $\times 3.0 \mathrm{~mm}$ wide and is slightly expanded at the point of attachment to the cone axis (fig. 8). Prominent scars on the cone axis exhibit a central coaly deposit about $2.0 \mathrm{~mm}$ in diameter representing remnants of the vascular tissue supplying the cone scale (fig. 10). The distal expanded portion of the ovulate cone scale is ca. $1.7 \mathrm{~cm}$ long $\times 1.2 \mathrm{~cm}$ wide. All of the ovulate cone scales are incomplete, since the matrix rarely fractured consistently in the plane of an entire scale. It was possible to determine the total number of ovulate cone scale components by observing the part and counterpart of several scales in various states of completeness. The most complete ovulate cone scale shows five components to one side of the central one, indicating that there were originally 11 components in a single plane comprising the complete cone scale (figs. 9, 11). This determination assumes that the complete cone scale exhibits bilateral symmetry and that the subtending bract apex lies along the axis of symmetry. This generalization holds true for all currently known fossil and recent conifers with completely flattened ovulate cone scales. Each component extends distally up to $6.0 \mathrm{~mm}$ beyond the expanded portion of the scale forming a narrow, toothlike lobe (figs. 7-9).

Since the cone scales fractured through the middle, features visible on the shale surfaces represent remnants of interior tissues, making it impossible to identify surface features such as ovule attachment scars. This preservational mode also reveals that the degree of foliar component fusion appears to vary at different levels within the scale. The expanded portions of some ovulate cone scale specimens show nearly complete lateral fusion of components on one surface, whereas components of the counterpart have deeper furrows between them (figs. 8,9 ). The groove representing the position of the bract apex is also visible at this level (fig. 9). Delevoryas and Hope (1987) noted the same pattern of splitting in ovulate cone scales of Florinostrobus andrewsii from the Triassic of North Carolina. These specimens graphically demonstrate the difficulty in determining the degree of fusion of ovulate cone scale components in compression-impression fossils and the necessity of examining both part and counterpart. This is particularly important, since the degree of fertile dwarf-shoot component fusion is considered an important character in some phylogenetic analyses (Miller 1988).

Individual subtending bracts of Conewagia longiloba are robust, $2.5 \mathrm{~mm}$ thick $\times 14.0 \mathrm{~mm}$ long $\times 14.0$ $\mathrm{mm}$ wide, and broadly attached to the cone axis. A slight lateral expansion forms a shoulder just below the acute apex (fig. 9). The bract and ovulate cone scale stalk are fused. Evidence for this fusion comes from prominent bract scars on the cone axis that are separated from the ovulate cone scale scar by a ridge of tissue representing the common adaxial and abaxial fusion surfaces of the bract and ovulate cone scale stalk, respectively (fig. 10). No vascular tissue scar or coaly deposit is discernible within the bract scar, indicating that the coaly material within the cone scale scar represents a common vascular supply for both the ovulate cone scale and bract. The bract shoulder and apex are not fused to the expanded portion of the ovulate cone scale but are situated adjacent to a groove on the abaxial scale surface (fig. 9).

\section{Putative Seeds}

Dispersed seeds occur at the Little Conewago Creek locality that may have been produced by this conifer. They are oblong-elliptical with blunt ends and possess a longitudinal, keel-like ridge or rudimentary wing (fig. 12). No micropyle or attachment scar was observed. The seed cuticles are covered with rows of papillae similar to those on the leaves of Conewagia (fig. 13). Such seeds have not been reported from any other localities. Although other conifer fossils occur at the Little Conewago Creek locality, they are unlikely to have produced these seeds. The common Pagiophyllum diffusum shoots have attached ovulate cones with in situ ovoid ovules bearing large wings unlike those of the seeds described here (Cornet 1977). In addition, the leaf cuticles of $P$. diffusum and $P$. simp. sonii have long and short epidermal hairs that have not been observed on the putative Conewagia seeds. Although the conspecificity of Conewagia and these seeds can only be proven by direct organic attachment, we suggest that the association and cuticular evidence presented here is compelling at this time.

\section{Discussion}

Ovulate cones like those described here have not been found at any other localities in the Triassic of eastern North America or elsewhere. Emmons (1856) reported foliage similar to that of Conewagia longi- 

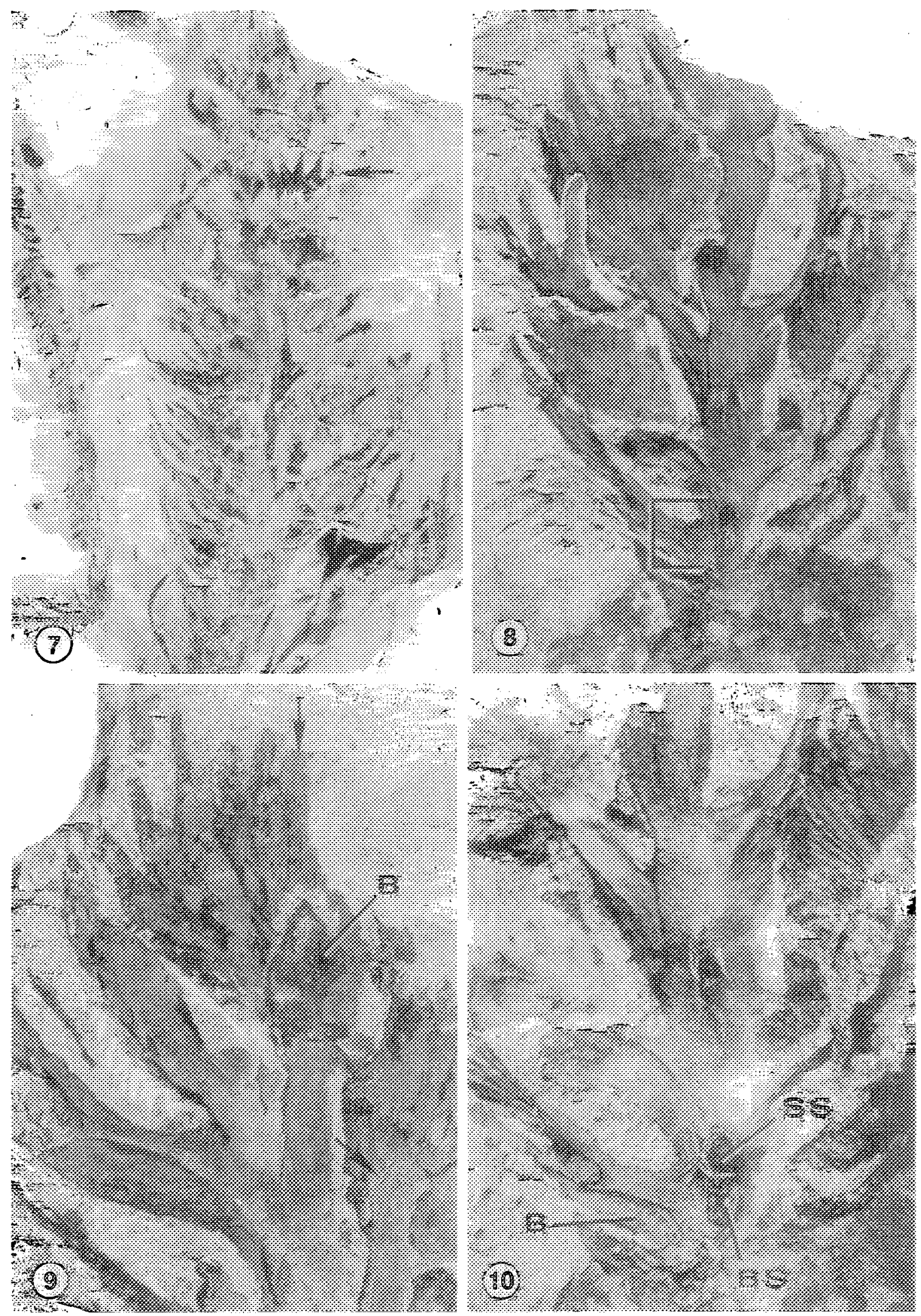

Figs. 7-10 Conewagia longiloba ovulate cones. Fig. 7, Detail of counterpart of cone in fig. 6 . Arrow indicates ovulate cone scale with several distal, toothlike lobes visible. No. T1-929. $\times$ 1.25. Fig. 8, Ovulate cone showing several helically arranged bract-scale complexes. Arrow indicates relatively complete cone scale. Bracket encloses bract and ovulate cone scale scars on cone axis. No. T1-926. $\times 1.5$. Fig. 9 , Detail of counterpart of cone in fig. 8 with subtending bract apex $(B)$ and shoulder exposed by excavation through ovulate cone scale. 


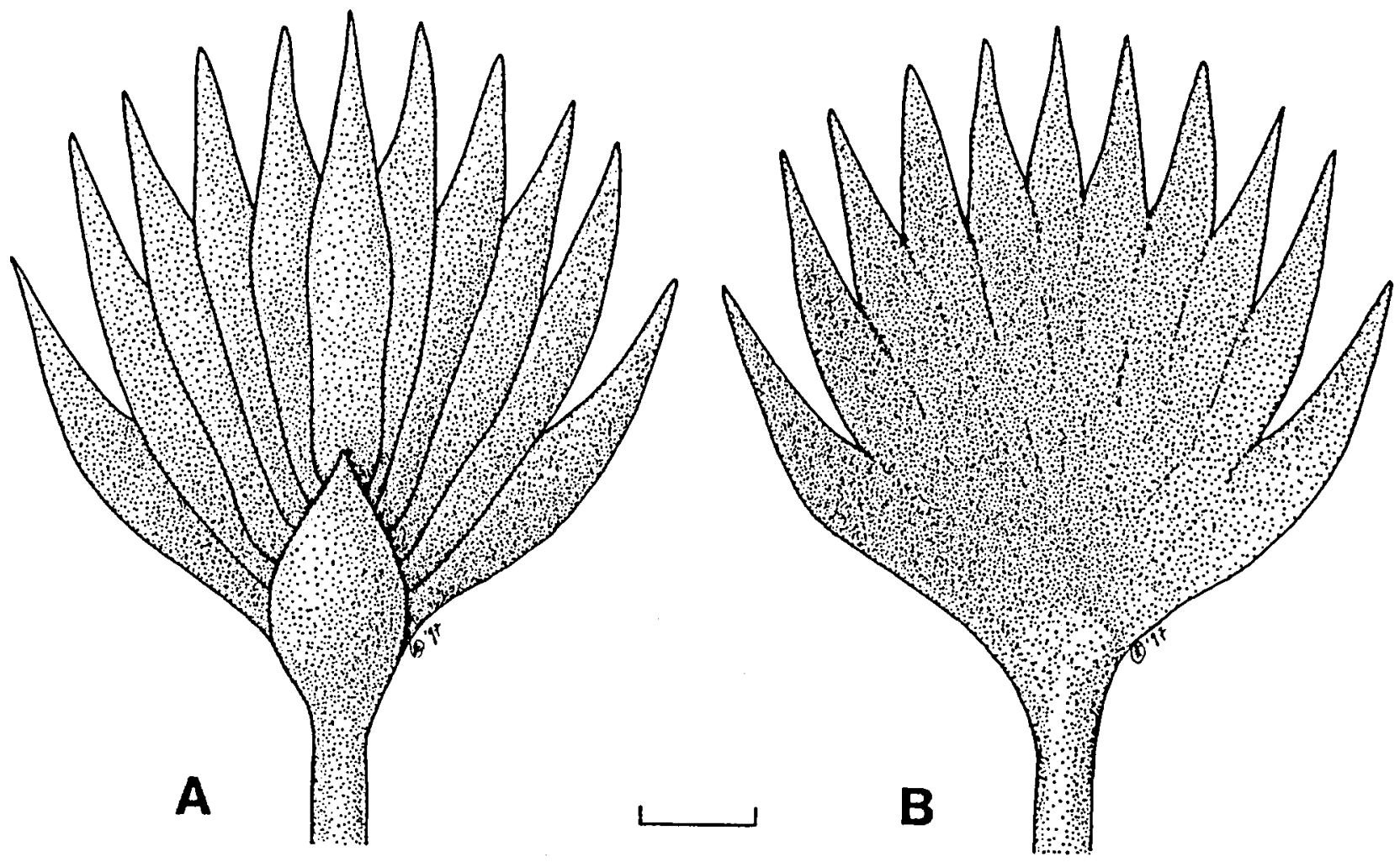

Fig. 11 Reconstructions of a Conewagia longiloba bract-scale complex. A, Abaxial view. B. Adaxial view. Note the deeper furrows between components on the abaxial side. Scale bar $=1.0 \mathrm{~cm}$.

loba from the Triassic of North Carolina that he named Walchia longifolius. Since Emmons's specimens are lost, we were unable to compare his material with the Pennsylvania specimens. Leafy shoots of Conewagia are similar in gross morphology to the Jurassic-Cretaceous form Elatides, which appears to be related to the modern taxodiaceous genus Cunninghamia (Miller 1990). However, leaves of Elatides and Cunninghamia lack epidermal papillae and usually possess a denticulate margin. The ovulate cones of Elatides and Cunninghamia are not at all similar to those of Conewagia.

Triassic-Jurassic occurrences of morphologically similar leaves have sometimes been assigned to the family Palissyaceae. This similarity is reflected in Wanner and Fontaine's (1900) original assignment of the foliage described here to Palissya sphenolepis. Recent reinvestigations of Palissya cones have revealed an unusual morphology consisting of helically arranged appendages bearing cuplike processes on their adaxial surfaces unlike those of any known fossil or recent conifer (Parris et al. 1995). Although the systematic affinities of Palissya cones and their relation- ships to the associated conifer-like shoots have been called into question, they are probably not coniferous, and are therefore not closely related to Conewagia. Although leaves of this general morphotype are common in the fossil record, the cuticles of Conewagia are too poorly preserved for further meaningful comparisons of the vegetative shoots.

Early Mesozoic conifers bearing ovulate cone scales with apical lobes or teeth have historically been assigned to the Voltziaceae (Miller 1977). It is becoming increasingly clear that this family is actually a paraphyletic assemblage of conifers including the basal members of some extant families as well as completely extinct groups (Miller 1988). For this reason, we have refrained from placing Conewagia in the Voltziaceae or any other family. As more is learned about the early Mesozoic conifers, it may eventually be appropriate to develop a more satisfactory family level taxonomy.

Ovulate cones of $C$. longiloba are somewhat similar to Florinostrobus andrewsii from the Late Triassic Pekin Formation of North Carolina (Delevoryas and Hope 1987). Both forms possess robust ovulate cone

$\leftarrow$

Upper arrow indicates center ovulate cone scale component. Lower arrow on adjacent cone scale indicates ridge along which bract apex is positioned. Note deep furrows between adjacent cone scale components relative to those of counterpart indicated by arrow in fig. 8 . No. T1927. $\times$ 3.8. Fig. 10, Detail of cone in fig. 8 . Narrow ridge of tissue between the cone scale scar $(S S)$ and bract scar $(B S)$ represents the common fusion surface of the bract and ovulate cone scale. Note adjacent ovulate cone scale and subtending bract $(B)$ in lateral view. No.
T1-926. $\times 3.9$. 


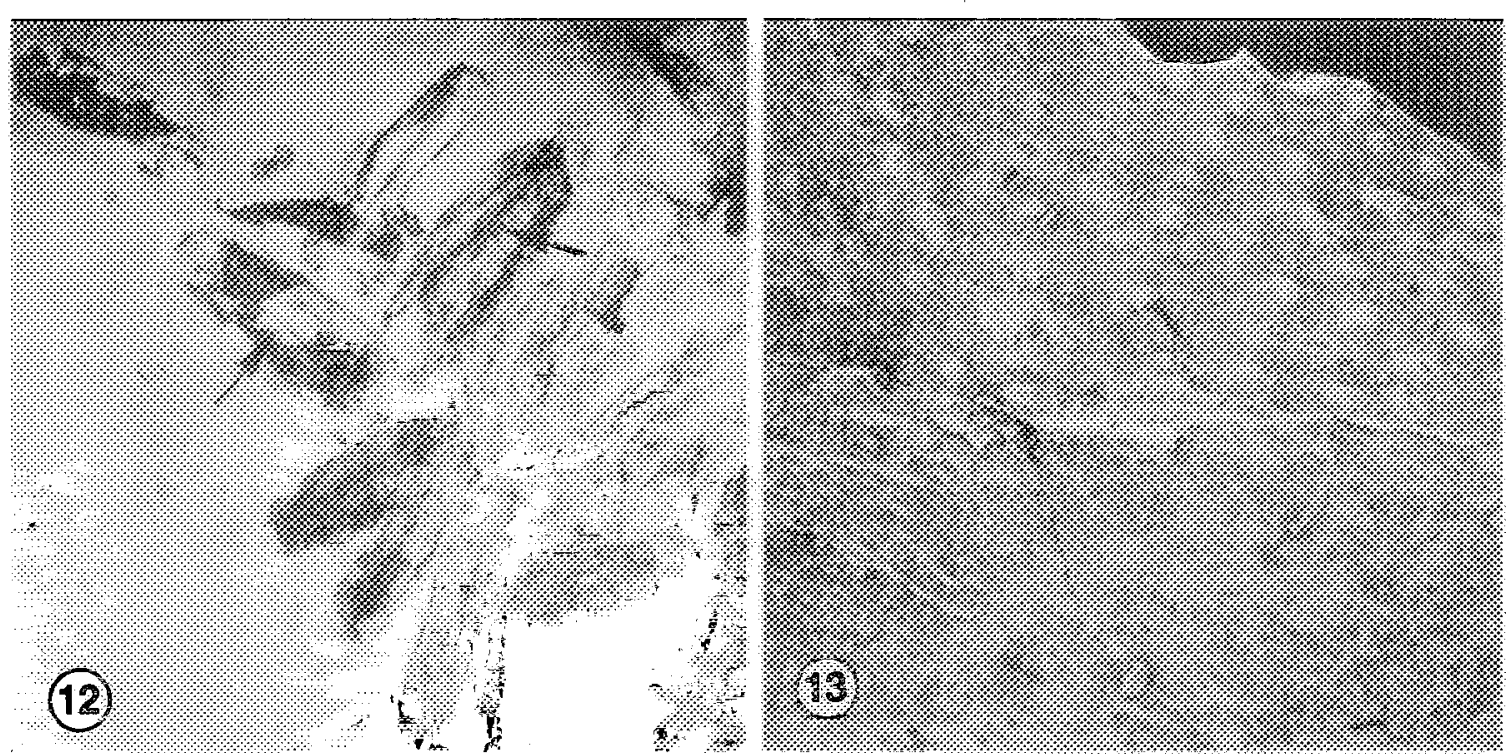

Figs. 12-13 Seeds associated with Conewagia longiloba. Fig. 12, Cluster of isolated seeds. Arrows indicate longitudinal ridges or rudimentary wings. No. T1-941. $\times$ 5.0. Fig. 13 , SEM of seed cuticle fragment showing patch of papillae in rows. No. T1-941. $\times 200$.

scales with long, narrow, stalklike bases and an apical expanded portion consisting of well-fused elements with apical lobes. However, Florinostrobus ovulate cone scales are composed of only five foliar components, and the apical lobes are more rounded. The bract is less conspicuous in Florinostrobus, but the apical region is similar in shape to that of Conewagia and was also positioned within a groove on the abaxial scale surface. The foliage and seeds of Florinostrobus remain unknown.

Several early Mesozoic conifers are known that possess pointed ovulate cone scale lobes somewhat similar to those of Conewagia. These forms may represent a distinct family including the genera Swedenborgia (Harris 1935), Aethophyllum (Grauvogel-Stamm 1978), Cycadocarpidium (Harris 1935), and the Gondwanan genus Telemachus (Anderson 1978). All of these conifers possess long ovulate cone scale stalks and show a similar degree of cone scale foliar component fusion as that of Conewagia. However, all possess only five ovulate cone scale foliar components, except Cycadocarpidium, which has two or three (Harris 1935). The length of the bract relative to the ovulate cone scale is about the same in Swedenborgia and Conewagia. However, in Aethophyllum the bract and ovulate cone scale are nearly equal in length, whereas the bract is much longer than the cone scale in most species of Cycadocarpidium and Telemachus. Furthermore, all of these genera differ from Conewagia in having broad, multiveined leaves of the Podozamites morphotype. Although Aethophyllum, Cycadocarpidium, Swedenborgia, and Telemachus may be closely related to each other (Grauvogel-Stamm 1978; Anderson 1978), they are only superficially similar to $\mathrm{Co}$ newagia. The features shared by Conewagia and the "voltziaceous" conifers discussed above appear to be mostly primitive characters common to many early
Mesozoic conifers rather than indicators of close phylogenetic relationships. Although the precise phylogenetic position of Conewagia remains obscure, the robust ovulate cone scale consisting of 11 components oriented in a single plane justifies recognizing this conifer as a distinct genus and may have important implications for current models of ovulate cone scale evolution.

\section{Phylogenetic Significance}

Some of the earliest conifers, such as Emporia, had up to 30 foliar components on the fertile dwarf-shoot (Mapes and Rothwell 1991). According to Florin's (1951) influential model, the major subsequent evolutionary trends involved progressive flattening of the fertile dwarf-shoot and loss or fusion of the foliar components. The ovulate cone scales of several early $\mathrm{Me}$ sozoic conifers have been viewed as representing intermediate morphologies in this transformation series. An unappreciated difficulty with this model is the fact that several modern conifers possess a greater number of ovulate cone scale foliar components than any previously described early Mesozoic forms. For example, ovulate cone scales of the extant taxodiaceous genera Glyptostrobus and Taxodium have 11 components (Takaso and Tomlinson 1990), and the phylogenetically isolated genus Sciadopitys typically has nine (Takaso and Tomlinson 1991). Although the unlobed ovulate cone scale of the Pinaceae retains no external evidence of constituent foliar components, Miller (1988) suggested that the presence of up to 20 vascular strands within the scale may indicate derivation from an ancestral form with numerous fertile dwarf-shoot foliar components. If this interpretation is correct, then a major temporal gap exits between Paleozoic and modern conifers with numerous cone scale components. This gap is particularly pronounced beginning 
in the Triassic when the ovulate cone scales of most forms have only five foliar components. Examples include Voltziopsis (Townrow 1967b), Parasciadopitys (Yao et al. 1997), Swedenborgia (Harris 1935), Aethophyllum (Grauvogel-Stamm 1978), Pachylepis (Kräusel 1952), Telemachus (Anderson 1978; Yao et al. 1993), Florinostrobus (Delevoryas and Hope 1975), and Voltzia coburgensis (Mägdefrau 1953). Until now, the greatest number of cone scale components identified in a Triassic conifer was eight in Glyptolepis (Schweitzer 1996; Axsmith and Taylor 1997). Unless there have been reversals in the general trends of fusion and reduction, the existence of early Mesozoic conifers with a larger number of ovulate cone scale components should have been expected. Although we are not suggesting any specific ancestor-descendant relationships, the morphology of Conewagia helps to fill this gap in the conifer fossil record by demonstrating that, during the Triassic, forms existed with many more ovulate cone scale components than were previously realized.

Although Florin (1951) attempted to base his phylogenetic models on a global synthesis of knowledge regarding fossil conifers, there was nevertheless a strong emphasis on European material. This was in part due to the historical reality that paleobotanical research in Europe preceded that of most other regions.
Although the conifer-rich paleofloras of Europe provided a satisfactory outline of the major trends in conifer evolution and continue to do so today (Kerp and Clement-Westerhof 1991), many gaps remain. Recent research demonstrates that paleofloras of other regions such as North America (Ash 1970; Delevoryas and Hope 1981; Mapes and Rothwell 1991), South America (Archangelsky and Cúneo 1987), Antarctica (Axsmith et al., in press), and western Angaraland (Meyen 1997) possess an important record of early conifers. In particular, the early Mesozoic rocks of eastern North America promise to shed additional light on this important interval in the evolution of conifers.

\section{Acknowledgments}

We thank Steven Shelley for generously allowing us to collect on his property. Sarah Fowell and Paul Olsen of the Lamont-Doherty Earth Observatory helped recover lost specimens. Peter A. Kroehler, John M. Kirby, Richard Bush, and Sonja Kaderly provided invaluable field assistance. Funding was provided by an Arthur Mix Scholarship from the University of Kansas Department of Botany and a Panorama Society grant from the University of Kansas Natural History Museum awarded to B. J. Axsmith. Additional funding was provided by NSF grant OPP-9315353 awarded to E. L. Taylor and T. N. Taylor.

\section{literature Gited}

Anderson HM 1978 Podozamites and associated cones and scales from the Upper Triassic Molteno Formation, Karoo Basin, South Africa. Palacontol Afr 21:57-77.

Archangelsky S, R Cúneo 1987 Ferugliocladaceac, a new conifer family from the Permian of Gondwana. Rev Palacobot Palynol $51: 3-30$.

Ash SR 1970 Pagiophyllum simpsonii, a new conifer from the Chinle Formation (Upper Triassic) of Arizona. J Paleontol 44: 945-952.

Axsmith BJ, TN Taylor 1997 The Triassic conifer seed cone Glyptolepis. Rev Palacobot Palynol 96:71-79.

Axsmith BJ, TN Taylor, EL Taylor In press Anatomically preserved leaves of the conifer Notophytum krauselii (Podocarpaceae) from the Triassic of Antarctica. Am J Bot.

Chaw SH, H Sung, H Long, A Zharkikh, W Li 1995 The phylogenetic positions of the conifer genera Amentotarus, Phyllocladus, and Nageia inferred from $18 \mathrm{~S}$ rRNA sequences. J Mol Evol 41: 224-230.

Cornet B 1977 Preliminary investigation of two Late Triassic conifers from York County, Pennsylvania. Pages 165-172 in RC Romans, ed. Geobotany. Plenum, New York.

Delevoryas T, RC Hope 1973 Fertile coniferophyte remains from the Late Triassic Deep River Basin, North Carolina. Am J Bot 60: 810-818.

- 1975 Voltzia andrewsii, n. sp., an Upper Triassic seed cone from North Carolina, U.S.A. Rev Palaeobot Palynol 20:67-74.

1981 More evidence for conifer diversity in the Upper Triassic of North Carolina. Am J Bot 68:1003-1007.

1987 Further observations on the Late Triassic conifers Compsostrobus neotericus and Voltzia andrewsii. Rev Palacobot Palynol 51:59-64.

Emmons E 1856 Geological report of the midland counties of North Carolina: North Carolina Geological Survey, 1852-1863. Putnam. New York. 323 pp.

Florin R 1951 Evolution in cordaites and conifers. Acta Horti Bergiani 15:285-388.
Grauvogel-Stamm L 1978 La flore du grès à Voltzia (Buntsandstein Supérieur) des Vosges du Nord (France) (Morphologic, anatomie, interprétations phylogénique et paléogeographique). Mem Sci Geol Univ Louis Pasteur Strasbourg Inst Geol 50:1-225.

Harris TM 1935 The fossil flora of Scoresby Sound east Greenland, Pan 4. Ginkgoales, Coniferales, Lycopodiales and isolated fructifications. Medd Gronl 112:1-176.

1969 Naming a fossil conifer. Bot Soc Bengal J Sen Mem Vol, pp. 243-252.

Hart J 1987 A cladistic analysis of the conifers: preliminary results. J Arnold Arbor Harv Univ 68:269-307.

Kerp H, JA Clement-Westerhof 1991 Aspects of Permian palaeobotany and palynology. XIl. The form genus Walchiostrobus Florin reconsidered. Nejb Geol Palaeontol Abh 183:257-268.

Kräusel R 1952 Pachylepis non. gen., eine neue Koniferen-Gattung aus dem süddeutschen Keuper. Senckénbergiana 32:343-350.

Mägdefrau K 1963 Dic Gattungen Voltzia und Glyptolepis im Mittleren Keuper von Hassfur (Main). Geol Bl NO-Bayern 13:95-98.

Mapes G, GW Rothwell 1991 Structure and relationships of primitive conifers. Nejb Geol Palaeontol Abh 183:269-287.

Meyen SV 1997 Permian conifers of Western Angaraland. Rev Palacobot Palynol 96:351-447.

Miller CN 1977 Mesozoic conifers. Bot Rev 43:219-280.

1988 The origin of the modern conifer families. Pages 448486 in CB Beck, ed. Origin and evolution of gymnosperms. Columbia University Press, New York.

1990 Stems and leaves of Cunninghamiostrobus goedertii from the Oligocene of Washington. Am J Bot 77:963-971.

Parris KM, AN Drinnan, DJ Cantrill 1995 Palissya cones from the Mesozoic of Australia and New Zealand. Alcheringa 19:87-111.

Schweitzer H-J 1996 Voltzia hexagona (Bischoff) Geinitz aus dem Mittleren Perm Westdeutschlands. Palaeontographica 239(B):1-22.

Stockey RA 1982 The Araucariaceac: an evolutionary perspective. Rev Palacobot Palynol 37:133-154.

Takaso T, PB Tomlinson 1989 Aspects of cone and ovule ontogeny in Cryptomeria. Am J Bot 77:1209-1221. 
1990 Cone and ovule ontogeny in Taxodium and Glyptostrobus (Taxodiaceae-Coniferales). Am J Bot 77:1209-1221.

Townrow JA $1967 a$ On Rissikia and Mataia, podocarpaccous conifers from the Lower Mesozoic of southern lands. Proc R Soc Tasmania 101:103-136.

$1967 b$ On Voltziopsis, a southern conifer of Lower Triassic age. Proc R Soc Tasmania 101:173-188.
Wanner A, WM Fontaine 1900 Triassic flora of York County, Pennsylvania. Pages $211-420$ in LS Ward, ed. Status of the Mesozoic floras of the United States. US Geol Surv Twentieth Ann Rept Pt II. Yao X, TN Taylor, EL Taylor 1993 The Triassic seed cone Telemachus from Antarctica. Rev Palaeobot Palynol 78:269-276.

1997 A taxodiaceous seed cone from the Triassic of Antarctica. Am J Bot 84:343-354. 
Copyright of International Journal of Plant Sciences is the property of University of Chicago Press and its content may not be copied or emailed to multiple sites or posted to a listserv without the copyright holder's express written permission. However, users may print, download, or email articles for individual use. 